\title{
Chomsky's School of Linguistics
}

\author{
Andarwati \\ Ketua Program Khusus Pengembangan Bahasa Inggris (PKPBI) UIN Malang
}

\begin{abstract}
Abstrak
Aliran linguistik Chomsky menyajikan konsep-konsep dan pandangan teoritis yang sangat berarti dalam pembentukan paradigma tentang hakekat dan ciri-ciri bahasa manusia. Penalaran yang melandasi ide-ide linguistik, khususnya tentang proses perolehan bahasa kedua alau bahasa asing, antara lain konsep kompetensi dan performansi, konsep strukur dalam dan struktur permukaan, dan konsep struktur sintaksis, memberikan kerangka pemikiran yang jelas tentang posisi pemahaman aliran linguistik ini dalam memandang bahasa manusia. Isu-isu yang dilahirkannya memberikan kontribusi yang bermakna dalam perkembangan linguistik dan implikasimya dalam pengajaran bahasa kedua atau bahasa asing..
\end{abstract}

\section{Introduction}

Chomsky is one of the prominent linguists in modern era. His linguistic ideas and good ability in theory construction have given contributions to the development of linguistics __ the study of language. He has gained great achievements in producing the concepts/ideas and theoretical insights which can 
structure our ways of thinking in linguistics. In this paper I present some important concepts/ideas and theory insights of Chomsky's school of linguistics.

\section{The Nature and Characteristics of Human Language}

One of Chomsky's achievements is his contribution concerning the concept of language. He defines language as a set (finite or infinite) of sentences, each finite in length and constructed out of a finite set of elements. 'The idea in this definition refers to both natural and unnatural languages. Human language, to him, is natural language.

Based on the first part of the definition, human language, as a natural language, consists of a set of infinite number of sentences. When we are speaking a language actually what we do is creating sentences in the language. We can make the collection of sentences longer and longer into an unlimited number. On the other hand, unnatural language has finite sentences. For example, the language used in computing machines, which is man-made, has a limited number of sentences.

The second part of the definition means that the number of elements of sentences in a language is limited. Indonesian language, for example, has only twenty six letters (a until z) consisting of twenty one consonants and five vowels.

Chomsky also views language as the mirror of mind. ${ }^{2}$ The statement means that what we do is actually the reflection of what is there in our mind. We, human beings, are not only doing activities but also having the ability to tell, by using the language, why we are doing the activities. This is one thing that differentiates humans from animals. Animals are doing things but are not able to tell why they are doing so.

In addition, language is a tool of thought. For Chomsky, language has two functions: for medium of communication and for a tool of thought. But, his concept then results in debates concerning whether the natural language we speak that is used for the medium of communication, is different from that of thought. Certain people think that what is used as the medium of thought is natural language, and not another different language. Some others, however, view that the language of thought is different from the natural language. 
Chomsky also gave contribution concerning the characteristics of human language. According to him, human language, as a natural language, has a system. The basis of the system is the sentence. Every analysis on human language is actually the analysis on its sentences. The system refers to the rules of how the sentences in the language operate. These rules are generally used as (a) the parameters of analysis whether utterances are grammatical or not, and (2) the basis for generating all grammatical sentences.

Another characteristic of human language is its complexity. Chomsky shows this characteristic by comparing these two English sentences:

(1) John is easy to please

(2) John is eager to please

The two sentences seem similar especially for non native speakers of English because both have the same sentence element sequence: Noun+Be+Adjective.+to+Infinitive Verb and the same sentence elements:

(1) Noun

(2) $\mathrm{Be}$

(3) Adjective

(4) To+Infinitive Verb

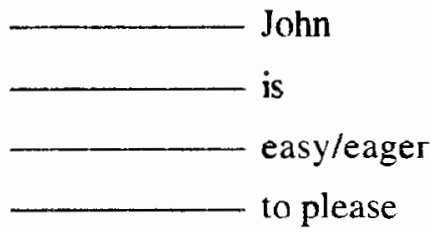

Native speakers of English, however, recognize the difference between them. John is easy to please means it is easy for someone to please John. John in this case is as the object of the pleasing. But, John is eager to please means that John is eager to do the activity of pleasing someone. Thus, John is the subject/ doer of the pleasing. This characteristic of human language might be a problem for second language learners of English.

Another issue related to the characteristics of human language is that human language is flexible. The English language's complexity can be seen, for example, from the possible different forms of sentences which can be used to construct Yes/No questions (requiring Yes or No answers), from the English sentence below:

Our new teacher is excellent in English literature.

Ulul Albab, Vol. 5 No. 1, 2004 
A variety of Yes/No questions for the sentence will be:

(1) Is our new teacher excellent in English literature? (regular Yes/No question)

(2) Our new teacher is excellent in English literature, isn't she? (negative tag)

(3) Our new teacher isn't excellent in English literature, is she? (positive tag)

(4) Our new teacher is excellent in English literature? (Echo)

This flexibility of the English language might confuse second language learners of English.

Furthermore, human language is also changing. From time to time human languages are changed as a result of the changing patterns of the societies in which they live. As what the people have in mind change, their languages change. The changing shows that human language is not static. The changing can be in the form of pronunciation or spelling changes, etc. For example, in Indonesian the words "materiil" and "spirituil" were acceptably used. But now, as a result of the Indonesian language engineering, the proper and accepted spellings are "material" and "spiritual". This characteristic of language will also be a source of problems for second or foreign language learners of Indonesian.

\section{Chomsky's Linguistics Theories and Issues in Second Language Acquisition (SLA)}

\section{A. Chomsky's Universal Grammar}

In the area of second language learning Chomsky gives contributions by presenting a Universal Grammar theory. His theory has the basis of insight that an innate biological endowment makes learning possible. Chomsky's Universal Grammar theory, which is a part of the so-called Government-Binding (GB) and also part of the Minimalist Program, views that humans are innately (i.e. genetically) endowed with universal language-specific knowledge called Universal Grammar (UG). In the "classical theory" it was vaguely introduced, and known as Language Acquisition Device (LAD). According to this theory, every child 
possessed a certain innate predisposition to induce the rules of the target language on the basis of the input to which he was exposed. These acquired rules would allow him to make generalizations about the language. In other word, to Chomsky, language acquisition is rule formation.

Universal Grammar consists of a set of such innate, abstract, linguistic principles, which govern what is possible in human language, thereby helping to alleviate the learning problem created by "poverty of the stimulus". Without such endowment (first or second) language learning will be impossible because the input data are too poor or deficient to allow acquisition ever to occur, much less to occur (so informally and so quickly) in about five years for child language. 3

Chomsky's school of linguistics views that the input is deficient because: (1) it is degenerate in the sense that it is marred by performance features, resulting in inadequate data for language learning, (2) it is degenerate in the sense that it is inadequate in various ways. Thus it does not usually contain information from which the learner could work out what is not possible in a given language.

Chomsky's views, however, have raised criticisms stating that (1) A good deal of complex syntax (as part of language learning) is not mastered until much later, until about age sixteen. Thus, learning occurs quickly and mostly complete at not as early as by the age of five, (2) Certain syntactic principles are not learnable, and therefore innate. But, the fact that learners do not produce ungrammatical utterances is evidence of innate linguistic knowledge.

\section{B. The concepts of "Competence" and" Performance"}

Chomsky's school of linguistics views that a linguistic theory primarily deals with an ideal speaker-listener, who knows his language perfectly and is unaffected by such conditions as disturbance of attention, physical constrains, psychological distractions, etc., which result in errors in applying this knowledge of language in actual use. The speaker-hearer's knowledge of language is what Chomsky calls as competence, and the actual use of language in concrete situations is called performance. ${ }^{4}$ To Chomsky, our knowledge of language (competence) is rulegoverned. Rules of the language sentence patterns govern the learner to have 
the knowledge about grammatical sentences of the language, those of the pronunciation govern him to have the knowledge of how to speak the language correctly. Every child learns to make generalization about language on the basis of his exposure to various kinds of linguistic experiences. One's performance is the reflection of his competence. What we see from one's language behaviors, however, is not a perfect reflection of what is in his competence. His performance might be defective because of physical or psychological constrains which then result in ill-formed sentences in his performance. To Chomsky, performance data constitute only one piece of evidence about the nature of one's competence. That's why the linguist's task in this case is to dig the underlying system of rules of one's language competence based on the data of performance.

Chomsky's Generative Grammar gives contribution to deal with this case. Universal grammar is a system of rules with finite of means that can generate infinite of sentences both well-formed and ill-formed sentences. ${ }^{5}$ This grammar gives an adequately structural description of how a sentence is understood by an ideal speaker-listener. The system of rules in this grammar consists of three main components: syntactic, phonological and semantic components. The phonological components determine the phonemic form of a sentence generated by the syntactic rules. It also relates a structure generated by the syntactic component to a phonetically represented signal. The semantic components determine the semantic interpretation of a sentence. It relates a structure represented by the syntactic component to its meaning representation.

\section{The concepts of "surface structure" and "deep structure"}

Chomsky sees a sentence as consisting of both "surface structure" and "deep structure". The surface structure of a sentence is a sentence structure which determines its phonetic interpretation. It is shown in its phonemic signal representation. Its structure consists of all sentence elements/words of which a sentence is composed. The sentence: Philosophy of Language is challenging, is the word sequence of what the speaker utters. It is the surface structure of the sentence. 
The deep structure of a sentence functions as a determiner for the semantic interpretation of the sentence. Related to this, there have been seven different ways of how the term "deep structure" is defined as shown in the following.

(1) Deep structure is the output of phrase structure rules.

(2) Deep structure is the input of transformational rules.

(3) Deep structure is the level at which lexical items are inserted.

(4) Deep structure is the level at which the concept of subject and object of a sentence are clearly defined.

(5) Deep structure is the level at which selection restriction rules are applied

(6) Deep structure is the level at which the meaning of a sentence is elicited/ revealed.

(7) Deep structure is the level at which ambiguity is solved.

Among the seven definitions, according to me, definition (6) gives a clear description that the intended meaning of a surface structure of a sentence can seen in its deep structure, and definition (7) shows a valuable function of a deep structure of a sentence — a helpful guide to solve the problem of sentence ambiguity. Below is an example of a problem of sentence ambiguity. The English sentence:

\section{She hates visiting relatives}

is semantically ambiguous. This sentence has one surface structure but the exact meaning the speaker has may be interpreted differently. One altemative meaning is She hates to visit her relatives. Another altemative meaning is She hates relatives who are visiting others. By showing the deep structure, the speaker's intended meaning will be clear.

In dealing with these surface and deep structures, Chomsky's Transformational Grammar (which is now replaced by "move $x$ " theory) is very valuable. It is a scientific grammar which aims to (1) provide a generalized explanation to a sentence construction/form, (2) show the relationships among sentence forms. Transformational grammar consists of the rules of rearranging various elements of sentences. In other words, it provides logical generalizations about a procedure for evaluating a grammar of any language. For example, the 
transformational grammar can be applied to know whether the English sentences (1) and (2) are similar.

(1) It is obvious that the earth is round

(2) That the earth is round is obvious

By (1) analyzing the deep structure, (2) making the pattern of structure change, (applying the transformational rules), we will find that both sentences (1) and (2) have similar meaning.

\section{The concept of Syntactic Structures}

Chomsky's great book Syntactic Structures has given a valuable contribution to the area of TEFL (Teaching English as a Foreign Language). In this book Chomsky presents such major things as the concept and the important role of syntax in the TEFL area.

Syntax is the study and processes by which sentences are constructed in particular languages. ${ }^{6}$ In other words, syntax is the study of language grammar.

Chomsky views that grammar of a language functions as a device that generates all of the grammatical sequences of the language (acceptable to a native speaker) and none of the ungrammatical ones. I agree with his idea about the function of language grammar as a device to generate all grammatical sentences. But, I don't agree with his concept of the grammatical sentences. To Chomsky, the grammatical sequences are those accepted by native speakers of the language. To me, however, it is not always so. In my opinions, we should categorize sentences as grammatical if they are correct based on the rules of the standard system of that language - in this case the rule of the language structures, others than these are ungrammatical ones although may be they are acceptable or communicative to native speakers of the language. We should identify the differences of grammatical, acceptable, communicative, and semantically relevant sentences.

Below are some examples of the real data of English sentences taken from the field.

Example 1: 
In Bali, there was a boy selling accessories. He said to a tourist: "Sir, buy me sir..". Then the tourist approached him and asked the price of the accessories.

The boy's sentence is grammatical because such pattern of imperative sentence is found in the English language system. The sentence is also communicative because the tourist understood what he meant. But it is semantically irrelevant because it is meaningless if he sold himself, as indicated by the word "me". His utterance was influenced by his Javanese language "Tukonono $a k u$ ", and then he just transferred his Javanese language into English without restructuring/adapting to the English language system

\section{Example 2:}

When I saw an English film, I found a dialogue between two speakers:

Speaker A: Who is speaking now?

Speaker B: It's me!

The sentence spoken by speaker $B$ is ungrammatical because the rule of the English grammar determines that the correct sentence should be It' $l$, but it is acceptable by native speakers of English.

Chomsky's school of linguistics views grammar as a major element of language so that the fundamental aims in linguistic analysis of a language should be: (1) to study the structure of the grammatical sequences of sentences in the language, and (2) to separate grammatical sequences from the ungrammatical sequences which are not sentences. And the goal of research on syntax should be related to the grammar construction of language.

Moreover, this school of linguistics views that although grammar can be used as a tool to generate grammatical sequences and differentiate grammatical from ungrammatical sequences, in fact it is not easy to identify that a certain sequence is grammatical because (1) the notion "grammatical" cannot be identified with "meaningful" or "significant" in any semantic sense and (2) the notion of "grammatical" in a language cannot be identified with the notion of "high order of statistical approximation to English statistical model of grammaticalness.

Chomsky used the two English sentences below as the example to clarify his ideas above. 
(1) Colorless green ideas sleep furiously

(2) Furiously sleep ideas green colorless

Any speaker of English will think that only sentence (1) is grammatical . But in fact is that it is semantically irrelevant, in other words, meaningless. To Chomsky, a sentence is grammatical if it is both syntactically and semantically well-formed. So sentence (1), according to him, violates " selectional restrictions".

Chomsky also emphasized that linguistic theory on syntactic structures is necessary because of its potential in giving the explanation in different types of analysis for linguistic levels: phoneme, morpheme, phrase structure, and such other linguistic phenomena as constructional homonymity ( a case when a certain phoneme sequence is analyzed in more than one way on some level).

Chomsky's jdeas, concepts, and linguistic theories are valuable contributions to the teaching of a second or foreign language area, that is as a guide for the second or foreign learners about (1) principles, processes, and procedures of sentence construction, (2) rules of language sentence patterns in order that they can differentiate the grammatical sentences from the ungrammatical ones, (3) the relationships among sentence elements, and (4) how to create sentences based on the correct standard language system, (5) analyzing the deep structure of sentences from their surface structure, and (6) rearranging various elements of English sentences.

\section{Conclusion}

Ideas, concepts, and theories in Chomsky's school of linguistics give a clear frame of thinking about the nature and characteristics of human language and language learning in the second language acquisition or foreign language acquisition area, as well as a valuable guide in the teaching of a second or foreign language area.

\section{Endnotes}

1 Chomsky, Noam. 1957. Syntactic Structures, paris: mouton Publishers, p.2 
2 Smith, Neil, 1999. Chomsky: Ideas and Ideals. United Kingdom: Cambridge University Press. p.3

3 Freeman, D.L Acquisition Research. \& Long, H.M. 1991. An Introduction to Second Language. USA: Longman Group UK Limited. p. 228-230

4 Smith, Opcit. p.28

5 Chomsky, Noam. 1965. Aspects of the Theory of Syntax. Cambridge: MIT Press In Kadarisman, A. Effendi. 2003. Schools of Linguistics: Selected Readings. p.3

s Chomsky, Opcit.p.l

\section{References:}

Chomsky, N. 1957. Syntactic Structures. Paris: Mouton Publishers.

Chomsky, N. 1965. Aspects of the Theory of Syntax. Cambridge: MIT Press. In Kadarisman, A. Effendi. 2003. Schools of linguistics: Selected Readings. Freeman, D.L. \& Long, M.H. 1991. An Introduction to Second Language Acquisition Research. USA: Longman Group UK Limited.

Smith, N. 1999. Chomshy: Ideas and Ideals. United Kingdom: Cambridge UniversityPress.

Thomas, O. 1965. Transformational Grammar and the Teacher of English. USA: Holt, Rinehart and Winston, Inc. 